\title{
Toleransi Antar Umat Beragama (Studi Kasus Keluarga Islam dan Keluarga Non Islam di 10 Ulu Palembang)
}

\author{
Yuniar Handayani, Ruskam Suaidi
}

Universitas Muhammadiyah Palembang yuniarhandayani4@gmail.com

\begin{tabular}{ll}
\hline \multicolumn{1}{c}{ Abstrak } \\
\hline Article History & This study aims to determine how the form of tolerance \\
Received :13-02-2020 & between religious communities in Rt 34 Kelurahan 10 \\
Revised :18-02-2020 & Ulu, Jakabaring Sub-district in Palembang and to find \\
Accepted :29-02-2020 & out how the relationship between Islamic families and \\
\hline Keywords: & non-Islamic families in Rt 34 Kelurahan 10 Ulu, \\
Tolerance Of & Jakabaring Sub-district in Palembang. The research \\
Intermediate Religion & approach uses a qualitative approach. The social \\
& situation in the community in the 10 Ulu Palembang \\
& neighborhood RT 34 that is Muslim and non-Muslim. \\
& The subjects of the study were the people in the 10 Ulu \\
& Palembang, RT 34 village who were Muslim and non- \\
& Muslim. Data collection techniques are observation, in- \\
& depth interviews, FGD, and documentation. Data \\
& analysis techniques use data presentation, data \\
& reduction, and data conclusions. The result of the \\
& research is that religious tolerance in RT 34 has \\
& occurred between Muslims and Confucianists. This can \\
& be seen from the location of the al Ghazali mosque with \\
& the kwan in goddess temples which are close together. \\
& And tolerance in the area of 9/10 ulu can also be seen \\
& from the harmonious life of the residents there. Even \\
though they have different religions, they still help and \\
help each other, if there are religious ceremonies carried \\
out by Muslims, Congolese and Buddhists.
\end{tabular}

\section{Pendahuluan}

Mayoritas umat Islam dalam hidup bermasyarakat memiliki sifat toleransi dan pluralistik dengan kelompok keagaman dan kelompok sosial, sehingga terwujud tujuan hidup manusia yang berdasarkan persaudaraan, penuh kasih sayang, dan harmoni (Abdul Munir, 1989: 50-51). Toleransi adalah sifat menghargai pendirian, kepercayaan, maupun pandangan yang berbeda dengan pendirian pribadi manusia (Umar Hasyim, 1979: 22). Dalam mewujudkan sifat dan sikap toleransi dalam kehidupan harus memperhatikan prinsip-prinsip sikap kelapangan dada terhadap sesama manusia. berlakunya toleransi dalam masyarakat karena ada terdapat perbedaan prinsipdan menghormati perbedaan atau prinsip orang lain tanpa mengorbankan prinsip sendiri (Daud Ali: 1989:80). Toleransi lahir dari agama Islam yang tercantum dalam al-Qur`an Surat al-Hujurat ayat 13 yang berbunyi: 


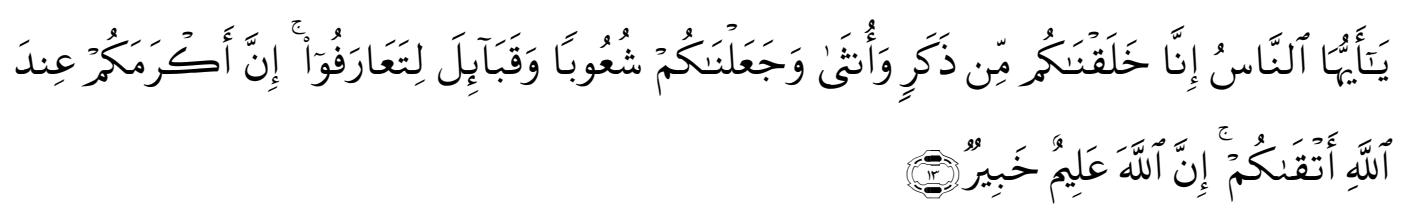

Hai manusia, Sesungguhnya Kami menciptakan kamu dari seorang laki-laki dan seorang perempuan dan menjadikan kamu berbangsa - bangsa dan bersukusuku supaya kamu saling kenal-mengenal.Sesungguhnya orang yang paling mulia diantara kamu disisi Allah ialah orang yang paling taqwa diantara kamu.Sesungguhnya Allah Maha mengetahui lagi Maha Mengenal.

Ayat di atas menjelaskan bahwa toleransi memiliki makna penafsiran negatif yaitu toleransi itu cukup mensyaratkan adanya sikap membiarkan dan tidak menyakiti orang atau kelompok lain baik yang berbeda maupun yang sama. Sedangkan penafsiran positif yaitu menyatakan bahwa toleransi tidak hanya sekedar seperti pertama (penafsiran negatif) tetapi harus adanya bantuan dan dukungan terhadap keberadaan orang lain atau kelompoklain.

Di dalam agama Islam orang muslimtidak boleh melakukan pemaksaan pada kaum agamalainnya, karena memaksakan suatu agama bertentangan dengan firman Allah SWT di dalam surat al-Kāfirūn: 1-6.

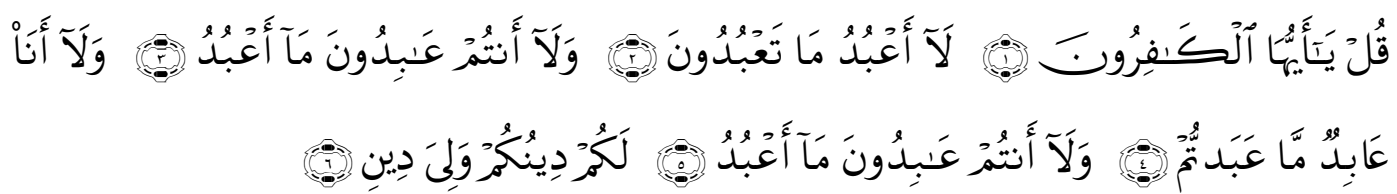

Katakanlah: "Hai orang-orang kafir, aku tidak akan menyembah apa yang kamu sembah. dan kamu bukan penyembah Tuhan yang aku sembah, dan aku tidak pernah menjadi penyembah apa yang kamu sembah, dan kamu tidak pernah (pula) menjadi penyembah Tuhan yang aku sembah. untukmu agamamu, dan untukkulah, agamaku."

Ayat di atas menjelaskan bahwa dalam bertoleransi, tidak memaksakan agama satu sama lain. Orang-orang muslim tidak menyembah apa yang di sembah oleh orang-orang kafir, begitu pula orang-orang kafir tidak menyembah apa yang di sembah oleh orang muslim. kita agama kita (orang muslim) dan bagi mereka agama mereka (orang kafir). Selanjutnya melindungi orang-orang selain muslim dan tidak saling memusuhi orang-orang selain muslim juga dilakuakn Nabi Muhammad SAW Ketika di Madinah. Kaum muslimin dianjurkan untuk bisahidup damai dengan masyarakat sesamanya walaupun berbedakeyakinan.Kaum Yahudi dan Nasrani yang jumlahnya sedikit dilindungi baik keamanannya maupun dalam beribadah. Dan diriwayatkan juga dalam Hadits Rasulullah Saw yang artinya: "Diriwayatkan bahwa Hisyam bin Hakim melihat seorang ahli dzimmah sedang berdiri di bawah terik matahari. Lalu dia bertanya kepada orang- orang di sekitarnya mereka berkata: orang tersebut adalah orang yang wajib membayar denda/upeti. Hisyam mendengar Rasulullah bersabda: siapa menyakiti manusia di dunia, Allah pasti menyiksanya di akhirat" (HR.Ahmad).

Selanjutnya manusia harus hidup damai dan rukum antar sesama manusia. Hidup rukun antar kaum muslim maupun non muslim seperti yang dilakukan oleh Rasulullah SAW akan membawa kehidupan yang damai dan sentosa, serta bersikap lembah lembut. Sikap yang mesti dimiliki sesama umat adalah sikap 
saling tolong menolong dengan sesama maupun antar manusia. Dengan adanya sikap tersebut membuat hati damai dan tenang. Hal ini juga dijelaskan dalam alQur'an pada penggalan surat al- Mā'idah ayat 2 sebagai berikut: Artinya: "Dan tolong-menolonglah kamu dalam (mengerjakan) kebajikan dan takwa, dan jangan tolong-menolong dalam berbuat dosa dan pelanggaran”.

Dari ayat tersebut sudah jelas bahwa di dalam al-Qur'an manusia mesti memiliki sikap tolong menolong itu juga seorang muslim dianjurkan untuk berbuat kebaikan di muka bumi ini dengan sesama makhluk Tuhan dan tidak diperbolehkan untuk berbuat kejahatan pada manusia. Di situ dikatakan untuk tidak mematuhi sesamanya.Selain itu juga dilarang tolong menolong dalam perbuatan yang tidak baik (perbuatan keji atau dosa).

Toleransi antar umat agama di kota palembang bisa kita lihat salah satunya di kelurahan 10 ulu palembang. Hal ini sudah menjadi kesepakatan para pemangku agama dalam pertemuan yang difasilitasi Kanwil Kemenag Sumsel, awal Agustus lalu.Salah satu bukti besarnya toleransi dan sikap kerukunan beragama di Palembang terpantau di Kelurahan 10 Ulu, Kecamatan jakabaring, Palembang. Di kawasan pinggiran Sungai Musi ini, kelompok agama yang berbeda bisa hidup berdampingan satu sama lain. Mereka bahkan saling membantu untuk berbagai momen ke agamaan dan hal kemasyarakatan lainnya.Yang sangat mencolok adalah adanya bangunan masjid yang berdiri tegak tepat tidak jauh dari bangunan kelenteng.Jika berada di atas Jembatan Ampera, bangunan merah khas kelenteng bisa terlihat dengan jelas. Begitu juga dengan plang nama masjid yang bahkan dipasang tepat di pagar turap Sungai Musi. Kendati berdekatan, jamaah kedua tempat ibadah itu tidak pernah bergesekan atau saling ganggu.Hal ini dibenarkan Ketua Majelis Umum Tridarma Sumsel, Chandra Husein.Dia mengatakan, kondisi kerukunan agama warga setempat sangat kondusif.Terasa sekali ketika momen perayaan hari besar, seperti Cap Go Meh.Halaman masjid kerap dipakai untuk parkir kendaraan dan warga setempat tidak mempermasalahkan rangkaian acara perayaan yang dijalani.Karena keunikan di atas penulis tertarik untuk membuat penelitian tentang toleransi antar umat beragama di kawasan 10 ulu Palembang.

Tujuan penelitian adalah untuk mengetahui bagaimana bentuk toleransi antar umat beragama di Rt 34 Kelurahan 10 Ulu Kecamatan Jakabaring di Palembang dan untuk mengetahui bagaimana hubungan keluarga Islam dengan keluarga non Islam di Rt 34 Kelurahan 10 Ulu Kecamatan Jakabaring di Palembang. Akbar Hasemi, dengan judul penelitian interaksi antar umat beragama (studi kasus Islam-kristen di kecaatan Sukakarya Kota Sabang). Hasil penelitian menunjukkan bahwa bentuk interaksi sosial antar Muslim dan Kristen di Kecamatan Sukakarya mengarah pada proses yang asosiatif, dimana didapati adanya pola hubungaan membaur antar masyarakatnya, yang ditandai adanya kerjasama, akomodasi dan asimilasi pada pola interkasi masyarakatnya.meskipun demikian, juga didapati adanya potensi yang mengarah pada bentuk interaksi yang disosiatif seperti ketegangan dan konflik namun dapat ditutupi dengan adanya peran pemerintah gampong dan kota dalam membina hungan antar pemeluk agama yang rukun dan harmonis. Dan Cahyo Pamungkas dengan judul penelitian Toleransi beragama dalam praktik social (studi kasus hubungan mayoritas dan minoritas agama di kabupaten Buleleng) dalam jurnal Epistemé, Vol. 9, No. 2, Desember 2014.Hasil penelitian adalah kelompok minortas Islam dan Kristen 
mengalami kesulitan ketika ingin mendirikan tempat ibadah meskipun persyaratan administrasi telah dipenuhi.Hal tersebut disebabkan karena Pemerintah Daerah menetapkan sejumlah kebijakan untuk melindungi identitas dan tradisi Hindu yang merupakan identitas utama orang Bali.Serta Muhammad Agus Mushodiq dalam jurnal Fikri Vol 2 No 2 2-17 IAIMNU Metro Lampung. Teori identitas dalam pluralism dan toleransi beragama (studi di desa Jrahim Gunung Wungkal, Pati) the Jrahi Village community tends to succeed in tackling the dark side of identity. They are able to resist ethnocentrism, racism, stereotypes, ethnocentrism and strengthings religions. The Jrahi village community still has homework in improving and strengtehenings the material of every religion that very citizen holds so that the general Jrahi community and their descendants will not, in particular, lose their religious identity from an early age.

\section{Metode Penelitian}

Pendekatan penelitian menggunakan pendekatan kualitatif (Basrowi dan Suwandi, 2008: 23).Situasi sosial pada kajian ilmiah ini terkonteks pada masyarakat di kelurahan 10 Ulu Palembang RT 34 yang beragama Islam dan beragama non Islam. Subjek penelitian atau key informent dalam penelitian ini pada masyarakat di kelurahan 10 Ulu Palembang RT 34 yang beragama Islam dan beragama non Islam. Tekhnik pengumpulan data yaitu observasi, wawancara mendalam, FGD, dan dokumentasi (M Iqbal Hasan, 2005: 7-10).Tekhnik analisa data menggunakan penyajian data, reduksi data, dan kesimpulan data (Afrizal, 2016: 180).

Tahapan-tahapan dalam penelitiannya adalah (1) persiapan (menyusun rancangan penelitian, memilih lokasi penelitian, mengurus perizinan, melakukan survey objek penelitian, memilih informan yang akan menjadi subjek penelitian, dan menyiapkan instrument penelitian yaitu instumen wawancara, FGD, dan observasi. (2) Lapangan (memahami dan memasuki lapangan dan aktif dalam kegiatan observasi, FGD, wawancara dan dokumentasi untuk mendapatkan informasi toleransi beragama. (3) pengolahan data (analisa data dengan menggunakan langkah-langkah dari Miles dan Hubermen, mengambil kesimpulan dan verfikasi apakah pelaksanaan toleransi beragama di di kelurahana 10 Ulu RT 34 sudah berjalan dengan baik atau belum, dan narasi hasil penelitian.

\section{Pembahasan}

Bentuk pola toleransi antar umat beragama di Rt 34 Kelurahan 10 Ulu Kecamatan Jakabaring di Palembang adalah dilihat dari segi religi yaitu masyarakat 10 ulu beragama Islam dan beragama Kong $\mathrm{Hu} \mathrm{Cu}$ saling menghargai akan ritual agama masing-masing. Praktik agama yang dilakukan masyarakat mencakup (ritual, khotbah, peringatan atau pemujaan tuhan, dewa atau dewi, pengorbanan, festival, pesta, trance, inisiasi, jasa penguburan, layanan pernikahan, meditasi, doa, musik, seni, tari, masyarakat layanan atau aspek lain dari kebudayaan manusia). Budaya pernikahan agama non Muslim mereka memakai hotel. Proses penguburan orang yang meninggal dunia yaitu dikremasi, harta orang yang meninggal itu dibagi - bagikan kepada orang atau anak - anak yang menunggu mayat sampai proses penguburan.

Dilihat dari segi Lingkungan hidup. pencemaran dipabrik pusri alhasil ikanikan disini banyak mati. Polusi udara di daerah perkotaan polusinya sudah 
tercema merr dengan banyaknya pabrik - pabrik dan kendaraan. Asap dan kabut dari kebakaran hutan.asap dan kabut dari kebakaran hutan sangat buruk untuk udara yang ada diperkotaan.Masyarakat banyak membuang sampah disembarangan tempat dan lebih banyak membuang dialiran sungai. Dengan permasalahan lingkungan hidup membuat mereka selalu kerja bakti dan gotong royong setiap minggu membersihkan lingkungan sekitarnya.

Dari segi Budaya Kehidupan Masyarakat, mereka saling membantu dan datang menghadiri acara.Kesenian masyarakat di 10 ulu yaitu kesenian pernikahan yang banyak dipakai yaitu organ tunggal.Moral atau prilaku masyarakatnya biasa - biasa saja. Jika melihat dari sisi luarnya orang - orang di 10 Ulu ini kelihatan seram namun setelah dikenal lebih dekat orang - orangnya baik - baik semua. Adat-istiadat masyarakat di 10 ulu sudah bercampur dengan orang yang sebelumnya asli tinggal dipedesaan.

Berdasarkan wawancara pola toleransi beragama masyarakat 10 ulu adalah: masyarakat di 10 Ulu Palembang tidak memaksakan orang lain untuk menganut agama kita, tidak mencela/menghina agama lain dengan alasan apapun, tidak melarang ataupun mengganggu umat agama lain untuk beribadah sesuai agama/kepercayaannya. Adapun pola toleransi beragama atas dasar kepentingan dan kebutuhan ekonomi yaitu kebutuhan ekonomi hanya berdasarkan kepentingan saja. Contoh: orang-orang non Islam banyak menarik atau mempekerjakan orangorang Islam untuk usahanya. Serta pola toleransi beragama atas dasar pada ajaran adat istiadat yaitu walaupun mereka berbeda etnis dan suku, mereka tetap saling menghargai satu sama lain. Berdasarkan hasil FGD yang ditujukan kepada tokoh masyarakat dan tokoh agama Rt 34 Kelurahan 10 Ulu Palembang adalah kehidupan beragama masyarakatRt 34 Kelurahan 10 Ulu Palembang adalah tentram antar masyarakat yang berbeda agama dan keyakinan. Tidak terjadi sikap saling curiga mencurigai dan selalu menghormati agama masing-masing. Semua lapisan masyarakat bersama-sama menciptakan suasana hayati yang rukun dan damai.

Sedangkan hubungan antara keduanya sangat baik. Masyarakat yang tinggal di daerah 9/ 10 ulu berasal dari beberapa suku, ada yang etnis Tionghoa, Etnis Arab, orang Pribumi (Palembang), suku jawa, dan lain sebagainya. Masyarakat di Rt. 34 Kelurahan 9/10 ulu Kecamatan JakabaringPalembang memiliki sikap toleransi antar umat beragama. Masyarakat muslim dan non muslim bisa saling hidup rukun bersama walaupun berbeda akidah dankeyakinan. Saat ada hari raya besar atau kegiatan upacara keagamaan di klenteng Dewi Kwan In contohnya seperti acara cap go meh di masyarakat muslim ikut membantu gotong-royong dalam membersihkan dan menyiapkan halaman parkir untuk kendaraan saat acara tersebut berlangsung. Saat ada hari raya besar atau kegiatan upacara keagamaan di masjid Al Ghazali contohnya saat hari Raya Idul Fitri dan Mauselid Nabi Muhammad SAW. Masyarakat non muslim juga ikut membantu dengan menyediakan lahan parkir dan membantu meyumbang dana saat acara yang di laksanakan umat muslim tersebut berlangsung.

Masyarakat muslim ikut menghargai dan menghormati upacara keagamaan yang berlangsung di klenteng tersebut. Dengan cara tidak mengganggu mereka saat upacara keagamaan tersebutberlansung. Saat adzan berkumandang reaksi masyarakat non Islam disana ada yang biasa saja dan tetap melaksanakan kegiatannya seperti biasa namun tetap merhargai dan menghormati saat umat 
muslim sedang mengumandangkan Adzan.Hal ini sudah menjadi kesepakatan para pemangku agama dalam pertemuan yang difasilitasi Kanwil Kemenag Sumsel, awal Agustus lalu.Salah satu bukti besarnya toleransi dan sikap kerukunan beragama di Palembang terpantau di Kelurahan 9- 10 Ulu, Kecamatan jakabaring, Palembang.

Di kawasan pinggiran Sungai Musi ini, kelompok agama yang berbeda bisa hidup berdampingan satu sama lain. Mereka bahkan saling membantu untuk berbagai momen keagamaan dan hal kemasyarakatan lainnya.Yang sangat mencolok adalah adanya bangunan masjid yang berdiri tegak tepat tidak jauh dari bangunan kelenteng.Jika berada di atas Jembatan Ampera, bangunan merah khas kelenteng bisa terlihat dengan jelas.Begitu juga dengan plang nama masjid yang bahkan dipasang tepat di pagar turap Sungai Musi. Kendati berdekatan, jamaah kedua tempat ibadah itu tidak pernah bergesekan atau saling ganggu. Hal ini dibenarkan Ketua Majelis Umum Tridarma Sumsel yaitu kondisi kerukunan agama warga setempat sangat kondusif. Terasa sekali ketika momen perayaan hari besar, seperti Cap Go Meh.Halaman masjid kerap dipakai untuk parkir kendaraan dan warga setempat tidak mempermasalahkan rangkaian acara perayaan yang dijalani.

Hasil wawancara dengan penduduk sekitar, ketua Rt 34 dan pengurus Masjid Al Ghazali yang ada di daerah 9/10 ulu palembang.yaitu sebagai berikut: Menurut bapak Eko Agustian (Ketua Rt di wilayah 9/10 ulu). Bentuk toleransi di daerah 10 Ulu saling menghormati dan menghargai, dan di daerah ini sangat rukun karena baik yang muslim ataupun non muslim tidak ada yang merasa terganggu dengan perbedaan agama tersebut. Saling membantu seperti gotong royong, karena warga non muslim juga suka membantu membersihkan lapangan yang ada disekitar masjid ketika warga muslim selesai dari acara seperti maulid dan lain-lain. Dan begitu pun sebaliknya, jika warga non muslim melakukan perayaan maka warga muslim akan membantu membersihkan. Sehingga terjadi hubungan timbal balik di antara kedua nya.respon orang non muslim yang berada di kawasan 10 ulu ini saat mendengar adzan berkumandang adalah dengan menghargai dan menghormati umat muslim saat melantunkan adzan.

Menurut Bapak Amir Hamza selau pengurus masjid Al- Ghazali Toleransi yang ada di daerah 9/10 ulu ini yaitu dengan cara saling tidak menggangu dan saling menghormati antar umat beragama juga saling membantu satu sama lain saat ada kegiatan atau upacara keagamaan yang berlangsung baik dari masjid al ghazali dan di klenteng dewi kwan in. Dan pembangunan masjid juga ada bantuan dana dari pihak klenteng. Dan saat bulan puasa juga terkadang masyarakat non muslim ikut membantu membangunkan sahur. Masyarakat di lingkungan 9/10 ulu ini saling hidup rukun bersama dan saling menghargai satu sama lainnya. Jika ada peringatan hari raya besar di klenteng masyarakat muslim ikut membantu mengawasi dan membersihkan halaman klenteng juga ikut membantu memakirkan kendaraaan yang ada. Begitupun sebalikya jika ada upacara keagamaan dari masyarakat muslim contohnya saat peringatan maulid Nabi Muhammad SAW. Mereka ikut membantu membersihkan dan memberi bantuan dana saat acara nya berlangsung. Respon orang non muslim yang berada di kawasan 10 ulu ini saat mendengar adzan berkumandang, Masyarakat yang ada di klenteng mereka menganut agama konghucu ikut menghormati jika adzan berkumandang dengan cara menghentikan kegiatan mereka sementara dan tidak 
mengganggu proses berlangsungnya ibadah.

Menurut Bapak Hendri (warga di sekitar Klenteng 9/10 ulu) bentuk toleransi antar umat beragama di daerah ini dengancara saling menghormati dan tidak mengganggu satu sama lain. saling hidup rukun bersama dan saling membantu satu sama lain. Saat ada peringatan hari raya besar umat islam seperti hari raya idul fitri maupun maulid Nabi Muhammad SAW pihak klenteng ikut membantu bergotong royong dan menyiapkan lahan parkir saat kegiatan acara berlangsung. Perayaan hari besar masyarakat yang ada di klenteng biasanya dilaksanakan kurang lebih 4 kali dalam setahun dan masyarakat muslim jg ikut membantu mengatur lahan parkir dan ikut membantu membersihkan halaman klenteng mereka yang ada di klenteng. Saat Adzan berkumandang reaksi masyarakat yang ada di klenteng biasa saja, dan masih terus melanjutkan kegiatan keagamaan mereka. Dikarenakan tidak akan mengganggu saat adzan berkumandang. Namun mereka tetapmengormati.

Menurut Ibu Hastati (warga di sekitar Masjid Al - Ghazali 9/10 ulu) bentuk toleransi antar umat beragama di daerah ini dengan cara hidup rukun bersama, saling menyapa satu sama lain dan juga saling tidak menggangu dan saling menghormati antar umat beragama juga saling membantu satu sama lain saat ada kegiatan atau upacara keagamaan yang berlangsung baik dari masjid al - ghazali dan di klenteng dewi kwan in. Saat ada hari raya besar yang ada di klenteng ada masyarakat muslim yang Ikut andil dalam melaksanakan kegiatan tersebut. Dan ikut membantu dengan cara bergotong-royong membersihkan halaman, mengatur parkir kendaraan, dan lain sebagainya. Respon orang non muslim yang berada di kawasan 10 ulu ini saat mendengar adzan berkumandang respon Masyarakat yang ada di klenteng mereka biasa saja.namun tetap menghormati jika adzan berkumandang.

\section{Simpulan}

Kesimpulan dari hasil penelitian di Rt 34 kelurahan 9/10 ulu kecamatan jakabaring palembang adalah memang benar ada toleransi yang terjadi di daerah 9/10 ulu antara umat muslim dengan umat konghucu yang ada disana. Hal ini bisa dilihat dari lokasi masjid al Ghazali dengan klenteng dewi kwan in yang saling berdekatan. Dan toleransi yang ada di daerah 9/10 ulu ini juga bisa dilihat dari rukunnya kehidupan warga disana. Walaupun berbeda agama, mereka tetap ikut membantu dan saling gotong-royong satu sama lain, jika ada upacara keagamaan yang dilaksanakan umat muslim maupun umat Konghucu maupun Budha disana. Saran adalah walaupun berbeda agama kita harus selalu senantiasa berbuat kebaikan dan saling tolong menolong satu sama lain, kita harus bisa menghargai dan menghormati mereka yang berbeda keyakinan dengan kita, dan tidak menggangu satu samalain. Tetap dipertahankan toleransi selama ini yang telah terwujud. 


\section{DAFTAR PUSTAKA}

Abdullah, Maskuri. 2001. Pluralisme Agama dan Kerukunan dalam Keagamaan, Jakarta: Buku Kompas.

Ali, Daud dkk. 1989. Islam Untuk Disiplin Ilmu Hukum Sosial dan Politik. Jakarta: BulanBintang.

Arikunto, Suharsimi. 2015. Prosedur Penelitian Suatu Pendekatan Praktek. Jakarta: Bumi Aksara.

Azra, Azyumardi. 2009. Toleransi Agama Dalam Masyarakat Majmuk: Perspektif Muslim Indonesia, dalam buku Merayakan Kebebasan Beragama (Bunga Rampai 70 Tahun Djohan Effendi, Jakarta: Kompas.

Hasan, M. Iqbal. 2005. Pokok-Pokok Statistik I. Jakarta: Bumi Aksara.

Hasyim, Umar. 1979.Toleransi dan Kemerdekaan Beragama dalam Islam Sebagai DasarMenuju Dialog dan Kerukunan Antar Agama. Surabaya: PT. Bina Ilmu.

Munir, Abdul. 1989. Pokok-pokok Ajaran NU. Solo: Ramdhani.

Said Agil Husin Al-Munawar, 2015.Fikih Hubungan Antar Agama, Jakarta: Ciputat Press.

Pamungkas, Cahyo. 2014. “Toleransi beragama dalam praktik social (studi kasus hubungan mayoritas dan minoritas agama di kabupaten Buleleng): Jurnal Epistemé Vol9 No 2 Desember 2014.

Agus, Muhamad Mushodiq. 2017. Teori Identitas dalam Pluralisme dan Toleransi Beragama (Studi di Desa Jrahim Gunung Wungkal, Pati) dalam FIKRI: Jurnal Kajian Agama, Sosial Dan Budaya Vol. 2 No 2017. 